\title{
Influence of Vehicle Traffic Emissions on Spatial Variation of Ozone and its Precursors in Air of Port Harcourt City, Nigeria
}

\author{
*1OKON, IE; ${ }^{2}$ OMONIYI, KI; ${ }^{2}$ PAUL, ED; ${ }^{2}$ EKWUMEMGBO, PA \\ *l Nigerian Institute of Transport Technology (NITT), Zaria, Kaduna State, Nigeria \\ ${ }^{2}$ Department of Chemistry, Ahmadu Bello University, Zaria \\ *Corresponding Author Email: idokon22@yahoo.com; Tel: 08032606180
}

\begin{abstract}
This study aimed at assessing the influence of vehicle traffic on spatial variation of ozone $\left(\mathrm{O}_{3}\right)$ and its vehicular emission precursors in the air of Port Harcourt city. Sampling was carried out in ten (10) sites, eight (8) located within the high traffic density area (study sites) and two (2) located within the very low traffic density area (reference sites). The precursor pollutants measured were nitrogen dioxide $\left(\mathrm{NO}_{2}\right)$, carbon monoxide $(\mathrm{CO})$ and volatile organic compounds (VOCSs). Ozone and the precursor pollutants were measured in situ using AeroQUAL 500 series portable ambient air analyzer while traffic flow survey was achieved by direct counting. Measurements were carried out at morning, evening and off-peak traffic periods respectively. The mean concentrations of ozone and the precursor pollutants were significantly higher $(\mathrm{p}=0.05)$ in the study sites than in the reference sites. Mean concentrations were higher at peak traffic periods than at off-peak traffic periods except for ozone that was higher at off-peak than at morning peak. There was significant correlation between traffic density and each of the pollutants including ozone. The spatial variability in concentration of pollutants was influenced by vehicular traffic. VOCs and $\mathrm{NO}_{2}$ levels were higher than the National Ambient Air Quality Standard (NAAQS) limit of $0.05 \mathrm{ppm}$ and $0.04-0.06 \mathrm{ppm}$ respectively, $\mathrm{O}_{3}$ concentration was below the standard limit $(0.06 \mathrm{ppm})$ but was at the verge of exceeding. Traffic emission within the city was significant and could be mitigated through regular monitoring and control.
\end{abstract}

DOI: https://dx.doi.org/10.4314/jasem.v25i8.11

Copyright: Copyright $(92021$ Okon et al. This is an open access article distributed under the Creative Commons Attribution License (CCL), which permits unrestricted use, distribution, and reproduction in any medium, provided the original work is properly cited.

Dates: Received: 10 May 2021; Revised: 28 June 2021; Accepted: 01 July 2021

Keywords: Vehicular emissions, Ozone, Traffic density, Precursor pollutants

Transport plays significant role in modern economic development as it creates time and place utility. Transportation expands overall accessibility in terms of business, education, employment and services (Emenike and Orjinmo, 2017). Road transport is a vital part of modern life; it provides opportunity to travel for personal development and professional activities and the economic development of the various regions of the world is facilitated by contemporary transport technology (Oderinde et al., 2016). This positive side of transport is not without problems, as it has led to environmental crisis in terms of air pollution and congestion (Oderinde et al., 2016). Good number of traffic-related studies has revealed that high traffic flow particularly in urban areas, contributes to more traffic emissions than low traffic flow (Nazatul et al., 2014). In the United State of America, motor vehicles were found to be responsible for nearly one half of smog-forming volatile organic compounds (VOCs), more than half of the nitrogen dioxide $\left(\mathrm{NO}_{2}\right)$ emissions, and about 75 percent of carbon monoxide (CO) emissions nationwide (USEPA, 2014 as sited in Emenike and Orjinmo, 2017). In general, there is traffic-related pollution or the tendency of it occurring in many parts of the world but more pronounced in developing countries, which experience higher levels of traffic-related pollution compared to developed countries because of inadequate pollution control measures or lack of it. There is an increase in vehicle ownership in Nigeria and this scenario has led to increase in traffic-related air pollution in Nigerian cities (Atubi, 2015). Port Harcourt city in particular is not left out from this current trend of road vehicle increase (Ucheje and Chidozie, 2015). This had led to traffic congestion especially at intersections and in turn increases combustion of fuel by vehicles engines, creating impact on air environment as a result of heavy emissions from these road vehicles (Zagha and Nwaogazie, 2015). Despite the rapid increase in traffic-related pollution in Nigeria, little attention has been given to the pollution damage caused by automobile transportation as evidenced in the very little number of research carried out on transport related pollution in Nigeria (Atubi, 2015). A survey by Okonkwo et al. (2014) on traffic flow in Port Harcourt revealed that there is always heavy traffic congestion in morning and evening hours at some junctions as 
Port-Harcourt is a fast growing city in terms of human population and commercial activities. Consequently, effects of emissions from this vehicular traffic have become a source of concern. From the studies on traffic-related pollution, only few like Emenike and Orjinmo (2017) relate traffic density to concentration of ozone and primary pollutants in the ambient air of Port Harcourt city. Ground level ozone $\left(\mathrm{O}_{3}\right)$ is one of the most harmful air pollutants (Marais et al., 2014), it is not directly emitted into the air by vehicle combustion processes but formed photochemically from the oxidation of volatile organic compounds in the presence of nitrogen oxides and other pollutants including carbon monoxide in the atmosphere (Sharma et al., 2017). In a simplified form, tropospheric ozone $\left(\mathrm{O}_{3}\right)$ formation processes from vehicular emission precursors $\left(\mathrm{NO}_{2}, \mathrm{CO}\right.$ and VOCs) are as follows:

\section{Photolysis of $\mathrm{NO}_{2}$}

\section{Oxidation of $\mathrm{CO}$}

\section{Oxidation of VOCs (RH)}

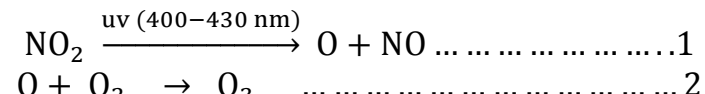$$
\mathrm{CO}+\mathrm{OH}^{\cdot} \quad \rightarrow \mathrm{CO}_{2}+\mathrm{H} \quad \ldots \ldots \ldots \ldots . . . . . . . . . . . . . .4
$$$$
\mathrm{H}+\mathrm{O}_{2} \rightarrow \mathrm{HO}_{2} \quad \ldots \ldots \ldots \ldots \ldots \ldots \ldots \ldots 4
$$$$
\mathrm{HO}_{2}+\mathrm{NO} \rightarrow \mathrm{OH}+\mathrm{NO}_{2} \ldots \ldots \ldots \ldots . .5
$$$$
\mathrm{NO}_{2} \stackrel{\mathrm{uv}(400-430 \mathrm{~nm})}{\longrightarrow} \mathrm{O}+\mathrm{NO} \ldots \ldots \ldots \ldots \ldots \ldots \ldots 6
$$

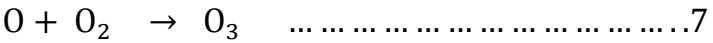$$
\text { Net: } \mathrm{CO}+2 \mathrm{O}_{2} \rightarrow \mathrm{CO}_{2}+\mathrm{O}_{3} \ldots \ldots \ldots \ldots \ldots \ldots . .8
$$

$$
\begin{aligned}
& \mathrm{RH}+\mathrm{OH}^{\cdot} \rightarrow \mathrm{R}+\mathrm{H}_{2} \mathrm{O} \ldots \ldots \ldots \ldots \ldots \ldots \ldots \ldots \ldots \ldots \ldots 9
\end{aligned}
$$

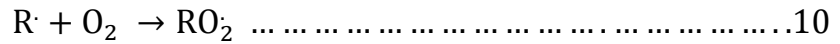

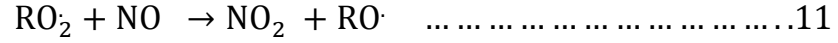

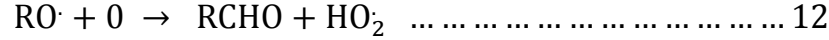

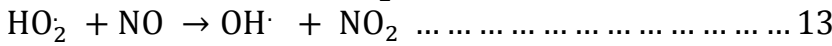

$$
\begin{aligned}
& \text { Net: } \mathrm{RH}+2 \mathrm{O}_{2}+2 \mathrm{NO} \rightarrow \mathrm{RCHO}+\mathrm{H}_{2} \mathrm{O}+2 \mathrm{NO}_{2} \ldots \ldots .14
\end{aligned}
$$

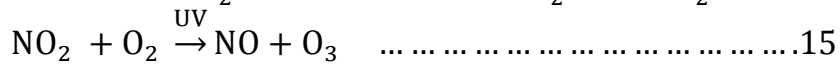

$$
\begin{aligned}
& \text { Yield: } \mathrm{RH}+2 \mathrm{O}_{2}+\mathrm{uv} \stackrel{\mathrm{NOx}, \mathrm{OH}^{-}}{\longrightarrow} \mathrm{RCHO}+\mathrm{H}_{2} \mathrm{O}+2 \mathrm{O}_{3} \quad . .16 \\
& \text { (William, 1994; Warmiński and Bęś, 2018) }
\end{aligned}
$$

The precursors too are also harmful to health at high exposure as $\mathrm{CO}$ causes blood poisoning by forming carboxyheamoglobin (Jason et al., 2017; Olusola et al., 2018). $\mathrm{NO}_{2}$ causes respiratory irritation and cardiovascular related mortality (Faustini et al., 2014). Furthermore, some VOCs are carcinogenic for humans (Wen-Tien, 2016). The objective of this study is to assess the influence of vehicle traffic emissions on spatial variation of ozone and its vehicular emission precursors $\left(\mathrm{NO}_{2}, \mathrm{CO}\right.$ and VOCs) in the air of Port Harcourt city, Nigeria

\section{MATERIALS AND METHODS}

Study Area: This study was conducted in Port Harcourt city, Rivers State, Nigeria which is located within latitudes $4^{\circ} 44^{\prime} 58.8^{\prime} ' \mathrm{~N} ; 4^{\circ} 56^{\prime} 4.6^{\prime} ' \mathrm{~N}$ and longitudes $6^{\circ} 52^{\prime} 7.2^{\prime} ' \mathrm{E} ; 7^{\circ} 7^{\prime} 37.7^{\prime}$ ' $\mathrm{E}$, the city experiences a tropical humid climate with lengthy and heavy rainy seasons and very short dry seasons (Emenike and Orjinmo, 2017). Port Harcourt is found in the coastal belt which is dominated by low lying coastal plains, which structurally belong to the sedimentary formations of Niger Delta, it covers an estimated area of 1811.6 square kilometer, slightly elevated though no significant structural control on the evolution of the drainage network (Chiadikobi et al., 2011). The city is the nucleus of administrative, commercial industrial, educational and other economic activities in the state and is commonly referred to as the treasure base of the nation.

Reconnaissance survey was conducted to be acquainted with the study area, from the survey, ten (10) traffic junctions were chosen as sampling sites considering hotspots, intersections and vehicular traffic levels, eight (8) of them located within the high traffic density area (study sites) while two (2) located within the very low traffic density area (reference sites). The eight (8) study sites in the busy area were all located along three important corridors in the city: Port Harcourt- Aba Express Road, East-West Road and the Ikwerre Road. These three major roads were chosen because of the high traffic flow resulting from them being main connectors to many feeder roads that link to almost every part of the city (Kio-Lawson and 
Dekor, 2014). The study site junctions were Water Lines (site 1), Air Force (site 2) and Rumukwurushi (site 3) along Port Harcourt- Aba Express Road; Eliogbolo (site 4), Rumuokoro (site 5) and Nkpolu (site 6) along East-West Road; Rumukwuta (site 7) and Rumuola (site 8) along Ikwerre Road. The reference sites junctions were Odi (site 9) and Opukuma (site 10) along Force Avenue.

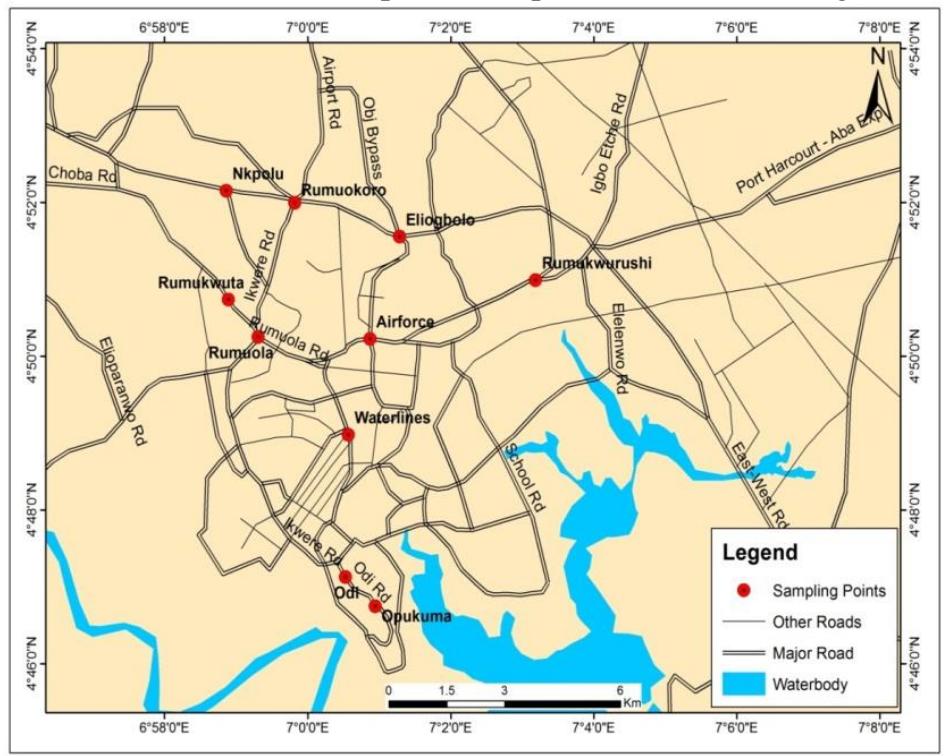

Fig 1: Map of Port Harcourt showing Sampling Sites

Data Collection and Analysis: Data on sampling points, concentration of $\mathrm{O}_{3}$ and the precursor pollutants $\left(\mathrm{NO}_{2}, \mathrm{CO}\right.$ and VOCs), and traffic flow survey were collected between December 2017 and November 2018. AeroQUAL 500 series (Aeroqual, New Zealand) portable ambient air analyzer with different sensors for individual gases was used for in situ measurement of $\mathrm{O}_{3}$ and the precursor pollutants ( $\mathrm{NO}_{2}, \mathrm{CO}$ and VOCs). Measurements were conducted with preference to favourable positions considering wind direction.

Traffic flow survey was achieved through collection of traffic density data at each of the sampling sites by direct counting. The time blocks chosen for measurement covered expected periods of high and low traffic (Utang and Peterside, 2011; Emenike and Orjinmo, 2017). The high traffic peaks were the "rush hours" of 7:00 - 9:00 am and 4:00 - 6:00 pm, which served as morning and evening peak traffic periods respectively. The expected periods of low traffic (12:00 - 2:00 pm) served as off-peak traffic period.

Statistical Data Analysis: Data were presented in Tables and graphs and further analysis was based on descriptive and inferential statistics. The descriptive statistics included mean and dispersion while the inferential statistics used included Student's T test and simple regression analysis. Data collection was carried out in triplicate for each of the parameters, which the mean served as the observed value.

\section{RESULTS AND DISCUSSION}

Air Pollutants: Figures 2, 3, 4 and 5 present the mean concentration of $\mathrm{NO}_{2}, \mathrm{CO}$, VOCs and $\mathrm{O}_{3}$ respectively at each of the sampling site. Maximal mean concentration for $\mathrm{NO}_{2}(0.079 \pm 0.007 \mathrm{ppm})$, for $\mathrm{CO}$ $(15.862 \pm 0.55 \mathrm{ppm})$, for VOCs $(1.813 \pm 0.113 \mathrm{ppm})$ and for $\mathrm{O}_{3}(0.053 \pm 0.008 \mathrm{ppm})$ was observed at sites $5,2,1$ and 5 respectively during evening peak as adjudged from results in Figures $2-5$. The maximal concentrations recorded at these sites during evening traffic period are not unconnected with the fact that evening hours coincides with more traffic congestion coupled with residual accumulation from other periods as was also established by Ucheje and Chiedozie (2015). Moreover, these sites are adjoined to more commercial and major intersections between the major roads making vehicles sometimes to be at "idle speed" because of the slow pace of traffic at which condition they tend to emit more pollutants. Minimal mean concentration for $\mathrm{NO}_{2}(0.034 \pm 0.003 \mathrm{ppm})$ was observed at sites 9 and 10 ; for $\mathrm{CO}(7.261 \pm 0.499 \mathrm{ppm})$ at site 10 ; for VOCs $(0.749 \pm 00.022 \mathrm{ppm})$ at site 9 and 10 ; for $\mathrm{O}_{3}(0.033 \pm 0.002)$ at site 9 . The minimal concentrations were all observed at off-peak except for ozone that was at morning peak. The minimal concentrations at sites 9 and 10 (reference sites) could result from them being located in the less busy area and do not have direct link to any of the arterial roads hence, having very low traffic flow with lesser volume of vehicular emissions. The mean concentration of $\mathrm{CO}$ was far higher than that of $\mathrm{NO}_{2}, \mathrm{VOCs}$, and $\mathrm{O}_{3}$ across 
periods; this could come from vehicle engines emitting more $\mathrm{CO}$ than the other pollutants. The highest level observed for $\mathrm{CO}$ among other pollutants agrees with a documented report by Ucheje and Chiedozie (2015) and Etim (2016). Concentrations of the pollutants were higher at peak traffic period than at off-peak traffic period except for $\mathrm{O}_{3}$ as presented in Figures 2 5 , this could be explained by higher number of vehicle at traffic peak period. Concentrations for $\mathrm{O}_{3}$ were higher at off-peak traffic period (afternoon) than at morning peak despite higher volume of precursor pollutants resulting from heavy traffic at morning as the concentration range $(0.034 \pm 0.002-0.051 \pm 0.008$ $\mathrm{ppm})$ for off-peak was higher than the range $(0.033 \pm$ $0.002-0.048 \pm 0.007 \mathrm{ppm}$ ) for morning peak as presented in Figure 5. This occurrence of lower amount of precursors giving rise to higher concentration of $\mathrm{O}_{3}$ at off-peak could be triggered by higher temperature as photochemical reactions needed for $\mathrm{O}_{3}$ formation occurs more at higher temperature (Melkonyan and Wagner, 2013).

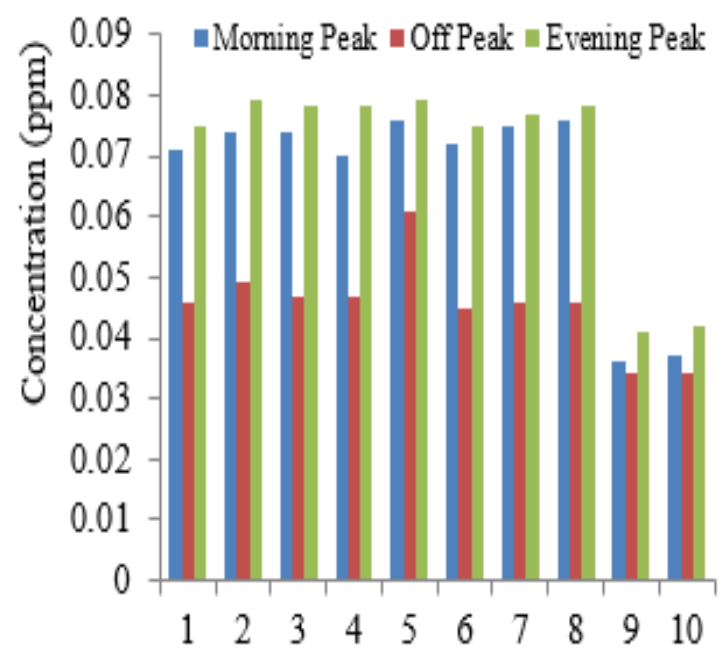

Fig 2: Mean Concentration of $\mathrm{NO}_{2}$ across Sites

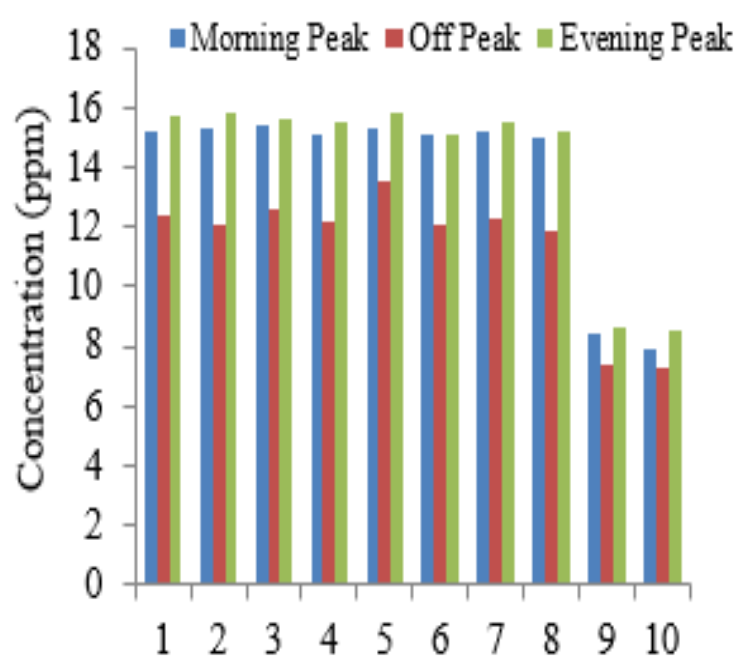

Fig 3: Mean Concentration of $\mathrm{CO}$ across Sites

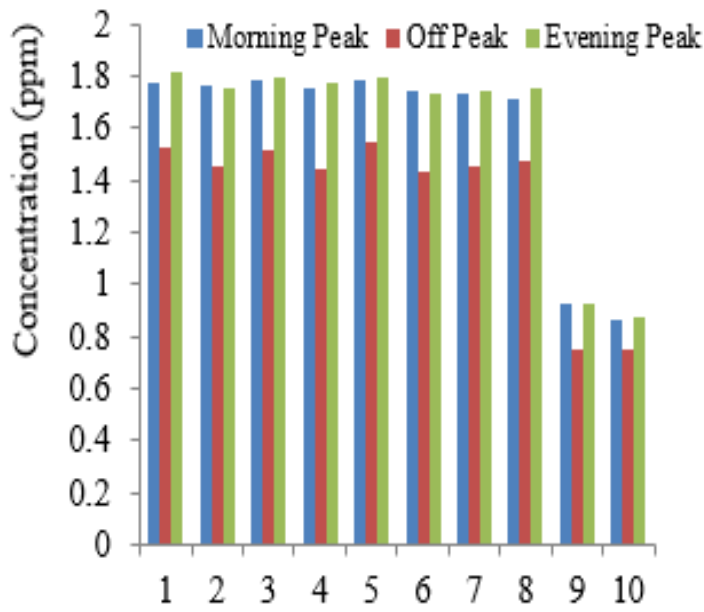

Fig 4: Mean Concentration of VOCs across Sites

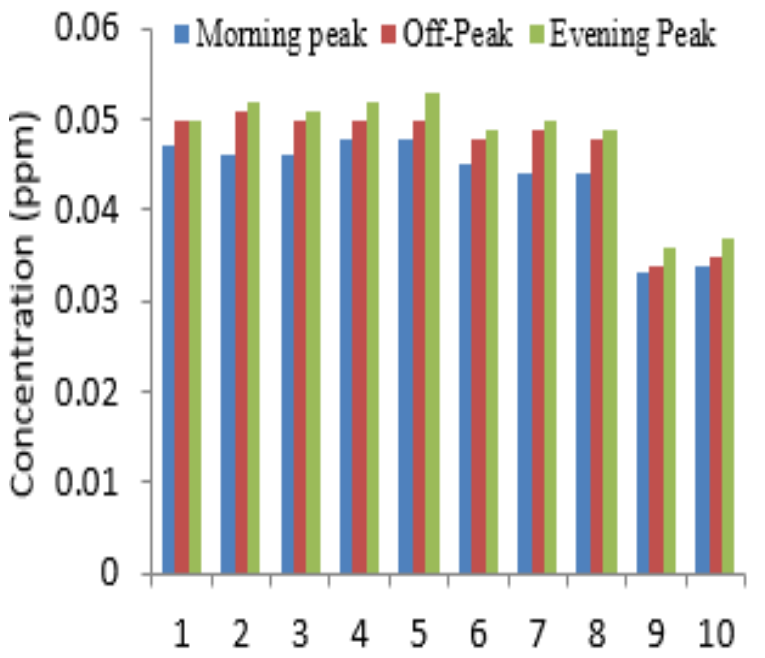

Fig 5: Mean Concentration of $\mathrm{O}_{3}$ across Sites 
Traffic Density: Figure 6 shows the mean spatial variation of traffic flow across traffic periods in vehicles per hour $(\mathrm{v} / \mathrm{h})$. Maximum value for traffic density $(1434 \pm 148 \mathrm{v} / \mathrm{h})$ was observed at site 3 during evening peak while the lowest density $(365 \pm 87 \mathrm{v} / \mathrm{h})$ was observed at site 10 during off-peak.

The range across study sites for morning peak, offpeak and evening peak were $1167 \pm 220-1363 \pm 273$ $\mathrm{v} / \mathrm{h}, 778 \pm 115-1042 \pm 98 \mathrm{v} / \mathrm{h}$ and $1241 \pm 248-1434$ $\pm 148 \mathrm{v} / \mathrm{h}$.

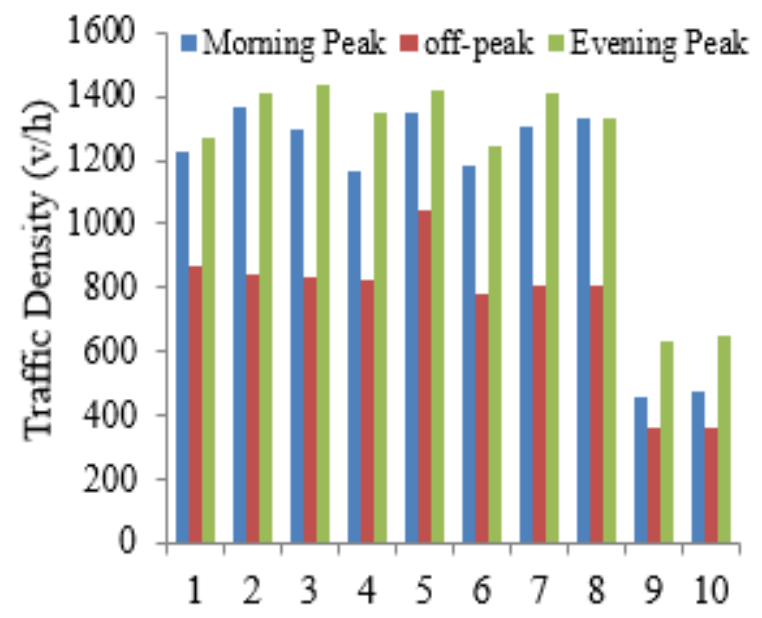

Fig 6: Average Traffic Density across Sites

These were higher than the range $458 \pm 124-479 \pm$ $116 \mathrm{v} / \mathrm{h}, 364 \pm 92-365 \pm 87 \mathrm{v} / \mathrm{h}$ and $629 \pm 134-647$ $\pm 70 \mathrm{v} / \mathrm{h}$ across the reference sites. The traffic density was in the order: evening peak > morning peak >> offpeak. The maximal traffic density observed during evening peak traffic period could be attributed to the smaller travel time (rush) during evening which leads to higher density of vehicles.

Influence of Vehicle Traffic on Concentration of Pollutants: Student's T-test was employed to compare the level of parameters across study sites to those of reference sites as shown in Table 1.

Traffic levels and concentrations for each of the pollutants in the study sites were significantly higher than in the reference sites across periods $(p=0.05)$. This higher concentration of air pollutants in the study sites could be as a result of high traffic volume, this agrees with the report of Ucheje and Chiedozie (2015) and Nazatul et al. (2014) where it was established that high traffic density contributes to more emissions than low traffic density. Table 2 present simple regression analyses for relationship between each of the pollutants and traffic density $(\mathrm{p}=0.05)$, the coefficient of determination $\left(\mathrm{R}^{2}\right)$ ranged from 0.875 to 0.995 across traffic periods. The high positive coefficient for all the pollutants signifies similarities of the emissions source and that the quantity of emissions generated by this source could influence the concentration of these pollutants in the air (Sharma et al., 2009).

\begin{tabular}{|c|c|c|c|c|c|c|}
\hline \multirow[t]{2}{*}{ Parameters } & Morning Peak & & Off Peak & & Evening Peak & \\
\hline & $T$ Calculated & T Critical & $T$ Calculated & T Critical & $T$ Calculated & TCritical \\
\hline $\mathrm{NO}_{2}$ & 23.660 & 2.200 & 8.770 & 2.200 & 20.520 & 2.200 \\
\hline $\mathrm{CO}$ & 43.580 & , & 47.790 & , & 40.950 & , \\
\hline VOCs & 87.900 & , & 32.840 & , & 30.300 & , \\
\hline Traffic Density & 28.510 & , & 30.710 & , & 21.820 &, \\
\hline
\end{tabular}

This high correlation between each of the pollutants and traffic density was validated using F test; the significance $\mathrm{F}$ for each of the pollutants was far less than the 0.05 significance level (very close to zero), implying that the correlation between each of the pollutants and traffic density was not from an offchance situation. This affirms that increase in traffic density could increase the volume of vehicular emissions, hence, higher concentrations of pollutants (Okonkwo et al., 2014). The high correlation between each of the pollutants and traffic density has revealed that traffic density had actually influenced the variability of these pollutants in the city of Port Harcourt.

Implication of Pollutants Concentration on Air Quality Standard: The impact of the pollutants concentration on air quality was assessed by comparing the concentrations observed for each of the pollutants with the Nigerian Ambient Air Quality Standard (NAAQS) limits. The mean ranges of concentration (in ppm) for $\mathrm{NO}_{2}$ across study sites: $0.070 \pm 0.009-0.076 \pm 0.007,0.045 \pm 0.003-0.061$ \pm 0.009 and $0.075 \pm 0.009-0.079 \pm 0.008$ at morning peak, off-peak and evening peak respectively were higher than the NAAQS limit range of $0.04-0.06$ ppm.

For $\mathrm{CO}$, the mean ranges of concentration (in $\mathrm{ppm}$ ) across study sites: $14.972 \pm 0.586-15.374 \pm 0.670$, $11.902 \pm 0.530-13.492 \pm 0.986$ and $15.144 \pm 0.615-$ $15.862 \pm 0.550$ at morning peak, off-peak and evening peak respectively were within the NAAQS limit range of $10-20 \mathrm{ppm}$. 
Table 2: Correlation Coefficients of Air Quality Parameters and Traffic Density

\begin{tabular}{|c|c|c|c|c|}
\hline \multicolumn{5}{|c|}{ Moming Peak Traffic Period } \\
\hline $\begin{array}{l}\text { Coefficients } \\
R \\
R^{2} \\
F\end{array}$ & $\begin{array}{l}\mathrm{NO}_{2} \\
0.995 \\
0.990 \\
802\end{array}$ & $\begin{array}{l}\mathrm{CO} \\
0.982 \\
0.963 \\
211\end{array}$ & $\begin{array}{l}\text { VOCs } \\
0.979 \\
0.959 \\
187\end{array}$ & $\begin{array}{l}\mathrm{O}_{3} \\
0.936 \\
0.875 \\
56.187\end{array}$ \\
\hline Sig. F & 0.000 & 0.000 & 0.000 & 0.000 \\
\hline \multicolumn{5}{|c|}{ Off- Peak Traffic Period (Aftemoon) } \\
\hline $\begin{array}{l}\mathrm{R} \\
\mathrm{R}^{2} \\
\mathrm{~F} \\
\text { Sig. F }\end{array}$ & $\begin{array}{l}\mathrm{NO}_{1} \\
0.943 \\
0.889 \\
64 \\
0.000\end{array}$ & $\begin{array}{l}\text { CO } \\
0.986 \\
0.972 \\
282 \\
0.000\end{array}$ & $\begin{array}{l}\text { VOCs } \\
0.968 \\
0.938 \\
121 \\
0.000\end{array}$ & $\begin{array}{l}\mathrm{O}_{3} \\
0.954 \\
0.910 \\
80.664 \\
0.000\end{array}$ \\
\hline & \multicolumn{4}{|c|}{ Evening Peak Traffic Period } \\
\hline $\begin{array}{l}\mathrm{R} \\
\mathrm{R}^{2} \\
\mathrm{~F} \\
\text { Sig. F }\end{array}$ & $\begin{array}{l}\mathrm{NO}_{2} \\
0.991 \\
0.981 \\
417 \\
0.000 \\
\end{array}$ & $\begin{array}{l}\text { CO } \\
0.986 \\
0.972 \\
282 \\
0.000 \\
\end{array}$ & $\begin{array}{l}\text { VOCs } \\
0.978 \\
0.957 \\
177 \\
0.000 \\
\end{array}$ & $\begin{array}{l}\mathrm{O}_{3} \\
0.984 \\
0.968 \\
241 \\
0.000\end{array}$ \\
\hline
\end{tabular}

For VOCs, the mean ranges of concentration (in ppm) across study sites: $1.711 \pm 0.061-1.786 \pm 0.072$, $1.438 \pm 0.098-1.552 \pm 0.134$ and $1.729 \pm 0.123-$ $1.813 \pm 0.113$ at morning peak, off-peak and evening peak respectively were higher than the NAAQS limit of $0.05 \mathrm{ppm}$. For $\mathrm{O}_{3}$, the concentration in ppm across study sites varies between $0.044 \pm 0.005-0.048 \pm$ $0.007,0.048 \pm 0.005-0.051 \pm 0.008,0.049 \pm 0.006-$ $0.053 \pm 0.008$ at morning peak, off-peak and evening peak respectively, showing that $\mathrm{O}_{3}$ concentrations were below the 0.060 ppm NAAQS limit. This result reveals that there was pollution from $\mathrm{NO}_{2}$ and VOCs as their range of concentrations were higher than the NAAQS limit. There was no pollution from $\mathrm{CO}$ and $\mathrm{O}_{3}$, however, the city was not very safe from ozone pollution as the maximal concentrations (ppm) of 0.051 and 0.053 at off-peak and evening peak respectively were at the verge of pollution.

Conclusion: From results obtained, mean concentration of $\mathrm{O}_{3}$ and each of the precursor pollutants was higher at peak traffic period than at offpeak. Maximal concentrations were observed at evening peak, followed by morning peak and then offpeak with exemption of $\mathrm{O}_{3}$ that was higher at off-peak than at morning peak. Concentrations were significantly higher in the study sites than reference sites. Variability in concentration of $\mathrm{O}_{3}$ and the precursors was influenced by vehicular traffic. $\mathrm{NO}_{2}$ and VOCs level were above standard limits while $\mathrm{CO}$ and $\mathrm{O}_{3}$ were within limit.

\section{REFERENCES}

Atubi, AO (2015). Transport and the environment: towards reducing road traffic emissions in Nigeria. Int. J. Sci. Technol. 4(1): (S/NO 9): 5878
Chiadikobi, KC; Omoboriowo, AO; Chiaghanam, OI; Opatola AO; Oyebanji, O (2011). Flood risk assessment of Port Harcourt, Rivers State, Nigeria. Adv. Appl. Sci. Res. 2 (6): 287-298.

Emenike, GC; Orjinmo, C (2017). Vehicular emissions around bus stops in Port Harcourt metropolis, Rivers State, Nigeria. Eur. J. Res. Soc. Sci. 5(3):19-33

Etim, EU (2016). Air pollution emission inventory along a major traffic route within Ibadan Metropolis, southwestern Nigeria. Afr. J. Environ. Sci. Technol. 10(11): $432-438$.

Faustini, A; Rapp, R; Forastiere, F (2014) Nitrogen dioxide and mortality: review and meta-analysis of long-term studies. Eur. Respir. J. 44:744-753

Kio-Lawson, D; Dekor, JB (2014). Port Harcourt, the garden city: a garden of residents nightmare. World Environ. 4(3):111 - 120.

Marais, EA; Jacob, DJ; Wecht, K; Lerot, C; Zhang, L; Yu, K; Kurosu, TP; Chance, K; Sauvage, B (2014). Anthropogenic emissions in Nigeria and implications for atmospheric ozone pollution: a view from space. Atmos. Environ. 99: 32-40.

Melkonyan, A; Wagner, P (2013). Ozone and its projection in regard to climate change. Atmospheric Environment 67, 287-295.

Nazatul, SZ; Nor, AR; Maisarah, S; Norrimi, RA (2014). A review of the effects of traffic, road characteristics, and meteorological conditions on ozone precursors from vehicle emissions. Int. J. Eng. Res. Technol. 3 (11): 1249 - 1252.

Oderinde, OK; Babajide, SO; Adeofun CO; Liu, S; Akinyemi, O (2016). Investigating the vehicular carbon monoxide concentration in the central region of Ogun State, Nigeria. J. Environ. Sci. Toxicol. Food Technol. 10(5 Ver 1): 90-98.

Jason, JR; Ling, W; Qinzi, X; Charles, FM; Sruti, S; Jesus, T; Mark, TG (2017). Carbon monoxide poisoning: pathogenesis, management, and future directions of therapy. Am. J. Respir. Crit. Care Med. 195(5): 596 - 606

Okonkwo, S; Okpala, K; Opara, MF (2014). Assessment of automobile induced pollution in an urban area; a case study of Port-Harcourt city, Rivers State, Nigeria. Chem. Proc. Eng. Res. 25: 12 - 15. 
Olusola, OO; Godson, REEA; Daniel, CU; Derek, GS (2018). Carboxyhaemoglobin levels among traders exposed to vehicular emissions in three motor parks in Ibadan, Nigeria. J. Environ. Public Health, Article ID 9174868)

Sharma, A; Massey, DD; Tuneja, A (2009). Horizontal gradient of traffic related air pollutants near a major highway in Agra, India. Indian J. Radio and Space Phys. 38: 338 - 346

Sharma, S; Sharma, P; Khare, M (2017). Photochemical transport modeling of tropospheric ozone: a review. Atmos. Environ. 159: 34-54

Ucheje, O; Chiedozie, IF (2015). Comparative analysis of vehicular emissions in urban and rural milieus: a case study of Port Harcourt and Etche in Rivers State, Nigeria. Arch. Appl. Sci. Res. 7(5):39- 44 .

USEPA (2014). Data from the air quality system. In: Emenike, GC; Orjinmo, C (2017). Vehicular emissions around bus stops in Port Harcourt metropolis, Rivers State, Nigeria. Eur. J. Res. Soc. Sci. 5(3):19-33
Utang, PB; Peterside, KS (2011). Spatio-temporal variation in urban vehicular emission in Port Harcourt city, Nigeria, Ethiopian J. Environ. Stud. Manage. 4(2): 38-51.

Warmiński, K; Bęś, A (2018). Atmospheric factors affecting a decrease in the night-time concentrations of tropospheric ozone in a lowpolluted urban area. Water Air Soil Pollute. 229(350): $1-13$

Wen-Tien, $\mathrm{T}$ (2016). Toxic volatile organic compounds (VOCs) in the atmospheric environment: regulatory aspects and monitoring in Japan and Korea. Environ. 3(23): 1- 7

William, PLC (1994). Evaluation of atmospheric processes for ozone formation from vehicle emissions. A paper Presented at the Automotive Technology Development Contractors' Coordinating Meeting. Dearborn MI, October 24-27.

Zagha, O; Nwaogazie, IL (2015). Roadside air pollution assessment in Port-Harcourt, Nigeria. Stand. Sci. Res. Essays. 3(3): $66-74$. 